\title{
Maintenance Interval towards Different Facilities and Services in High-Rise Housing
}

\author{
Cheong Peng Au-Yong ${ }^{1, *}$, Azlan Shah Ali ${ }^{2}$, Shirley Jin Lin Chua ${ }^{3}$, Adi Irfan Che-Ani ${ }^{4}$ \\ ${ }_{1,2,3}$ Centre for Building, Construction \& Tropical Architecture (BuCTA), Faculty of Built \\ Environment, University of Malaya, 50603 Kuala Lumpur, Malaysia. \\ ${ }^{4}$ Department of Architecture, Faculty of Engineering \& Built Environment, Universiti \\ Kebangsaan Malaysia (UKM), 43600 UKM Bangi, Selangor, Malaysia. \\ *auyongcp@um.edu.my
}

Received: 18 July 2017 Final Version Received: 10 January 2018

\begin{abstract}
Maintaining facilities and services of high-rise residential buildings is crucial in order to ensure the buildings operate optimally and achieve better user satisfaction. The purpose of this research is to deal with the appropriate maintenance interval for two different group of facilities and services namely essential and value-added specifically for high-rise residential buildings. Questionnaire survey was conducted among maintenance personnel who manage high-rise housing throughout Peninsular Malaysia. A total of 321 returned questionnaires were considered valid and analysed to rank the maintenance interval for the variables identified from literature review. The result revealed that different type of building facilities and services has different maintenance interval. It is also proven via Friedman test that the maintenance interval of facilities and services is significantly different. It is mainly because essential facilities and services are vital to support the building user daily routine. Thus, the maintenance personnel should plan and execute maintenance work based on the appropriate maintenance interval. Since this research only compares the differences of maintenance interval for different building facilities and services in common practice, further research is recommended to investigate the relationship between maintenance intervals and its performance in terms of cost and quality.
\end{abstract}

Keywords: building maintenance; maintenance interval; building facilities; building services; residential building; maintenance cost

\section{INTRODUCTION}

Abdullah Sani et al. (2012) defined maintenance culture as "the value, way of thinking, behaviour, perception, and the underlying assumptions of any person or group or society that considers maintenance as a matter that is important (priority) and practices it in their life". He further mentioned that a person or group who practises maintenance culture would intend to maintain, preserve and protect the facilities from being deteriorated or damaged. However, there is still lack of concern regarding building maintenance in Malaysia, particularly the life cycle and performance of building facilities and services (Zawawi et al., 2011). Whereby, preventive maintenance is somehow neglected or under-utilised, as the public do not see the direct benefits of it.

Ignorance towards the importance of preventive maintenance in domestic housing industry is common in Malaysia (Tiun, 2009; Yusof et al., 2012). Whereby, inadequate maintenance fund is the root cause of practising inappropriate maintenance operations in majority of the high- rise housing schemes (Abd Wahab et al., 2016). As a result, dilapidation of the residential buildings, facilities and services happen progressively, leading to residents'

dissatisfaction (Abdul Karim, 2012). Indeed, it is crucial to evolve the maintenance quality in high-rise housings in order to realise the strategic thrust of providing adequate, affordable, and quality houses, with greater prominence given to a good environment under Malaysian Vision 2020 (Zairul et al., 2015).

Various researches have proposed the scheduled maintenance as a strategy to improve the maintenance performance (Au-Yong et al., 2016; Flores-Colen \& De Brito, 2010; Forster \& Kayan, 2009). Meanwhile, Hameed et al. (2016) noted that systematic inspection and maintenance interval helps to mitigate unwanted failure, maintenance cost and risk exposure. Taking into cognisance the issue of inadequate maintenance fund, it is critical to study the appropriate maintenance interval that ensures the maintenance efficiency and affordability (Edward et al., 1998; Eti et al., 2006; Irigaray \& 
Gilabert, 2009; Wu et al., 2006). Whereby, Yang et al. (2016) argued that execution of different inspection and maintenance interval policies based on the component complexity is possible to prevent excessive maintenance while prolonging the system lifetime. Thus, this paper aims to compare the maintenance interval towards different building facilities and services of high-rise residential building.

\section{Maintenance of Facilities \& Services in High-Rise Housings}

Residential buildings dilapidate as a result of heavy usage and stress under different circumstances, such as wear and tear, climate change and ageing process. Taking into cognisance the high occupancy rate, regular maintenance and repair are necessary to decrease the rate of dilapidation or retain the buildings and systems in standard operating condition. Furthermore, they help to secure the property value and guarantee high return on investment (Tiun, 2009). Besides that, Yusof et al. (2012) stated that performing maintenance works is meant to keep the building habitable and operable.

Due to the evolution and advancement of construction technology, the public is looking forward to quality living rather than living space only. When people are financially capable, they prefer to buy a property equipped with valueadded facilities such as gymnasium, sauna, swimming pool, landscaping, etc. on top of the basic building services like lift, power supply, water supply, and others (Tiun, 2009). The building facilities and services enhance the living experience and then lead to the residential satisfaction (Mohit et al., 2010). Nevertheless, maintenance of those building facilities and services is unavoidable to ensure their operability and functionality. Additionally, the maintenance works safeguard economic and social wellbeing while reducing carbon footprints (Chiang et al., 2015).

\subsection{Essential Facilities \& Services}

High-rise residential buildings include basic facilities such as water supply system, power supply system, firefighting system, vertical transportation system, air conditioning and security system. These are the essential facilities and services that must be provided as to fulfil the needs of occupant's daily routine activities inside a building (Abdul-Rahman Hamzah et al., 2014). Additionally, the construct or design of these facilities must be comply with the regulation standard and housing guidelines such as Strata Title Act, Electricity Regulations, Fire
Safety Regulation, etc. Furthermore, the maintenance program of these facilities components is compulsory as stated in the enactment act in order to prolong its lifespan and safety (Motawa \& Almarshad, 2013). In highrise residential building, the essential facilities and services are tabulated in Table 1 .

Table 1: Essential facilities and services in highrise residential building

\begin{tabular}{|c|c|}
\hline $\begin{array}{l}\text { Facilities and } \\
\text { Services }\end{array}$ & Citations \\
\hline Lift system & $\begin{array}{l}\text { Alonso Pérez et al. (2010); } \\
\text { Kamarazaly et al. (2013) }\end{array}$ \\
\hline Water supply & $\begin{array}{l}\text { Goulden and Spence (2015); } \\
\text { IFMA (2015); Park et al. } \\
(2015)\end{array}$ \\
\hline Power supply & $\begin{array}{l}\text { Suruhanjaya Tenaga (1994); } \\
\text { Moreno-Muñoz et al. } \\
\text { (2007); Meng (2013); } \\
\text { Hassanain et al. (2015a); } \\
\text { Suárez-Warden and } \\
\text { Mendívil (2015) }\end{array}$ \\
\hline Security system & $\begin{array}{l}\text { Williamson et al. (2013); } \\
\text { Caballé et al. (2015); } \\
\text { Walker and Tough (2015) }\end{array}$ \\
\hline $\begin{array}{l}\text { Fire protection } \\
\text { system }\end{array}$ & $\begin{array}{l}\text { Azmi et al. (2009); Harris } \\
\text { (2011); Xin and Huang } \\
\text { (2013); Festag (2016); } \\
\text { Fleming (2016); Yao et al. } \\
(2016)\end{array}$ \\
\hline Cleaning services & $\begin{array}{l}\text { Choi et al. (2015); Leone et } \\
\text { al. (2015); Ait Bamai et al. } \\
(2016) \text {; Fattorini et al. } \\
(2016)\end{array}$ \\
\hline
\end{tabular}

\subsection{Value-added Facilities \& Services}

On the other hand, value-added facilities and services offer health and wellbeing spaces such as recreational facilities, swimming pool, landscape garden, and also aesthetic value by cleaning and painting. Moreover, these facilities provide spaces for social and physical activities that are linked to residential satisfaction and quality of life accordance to the urban lifestyle. For instance, the green open space available as one of the value-added facilities would encourage the residents to access outdoor space filled with green environment for variety of social and physical activities (Cao, 2016). The value-added facilities and services in high-rise residential building are shown in Table 2 . 
Table 2: Value-added facilities and services in high-rise residential building

\begin{tabular}{ll}
\hline $\begin{array}{l}\text { Facilities and } \\
\text { Services }\end{array}$ & Citations \\
\hline $\begin{array}{l}\text { Landscaping and } \\
\text { gardening }\end{array}$ & $\begin{array}{l}\text { Olesen et al. (2013); } \\
\text { Korpela et al. (2015); } \\
\text { Othman et al. (2015); Wu } \\
\text { et al. (2016) }\end{array}$ \\
Lo et al. (2016); Pan et al. \\
(2016); Said et al. (2016) \\
Righi et al. (2014); \\
Swimming pool \\
$\begin{array}{l}\text { Arkanova and Kuznetsova } \\
\text { (2016); Tardif et al. } \\
\text { (2016); Tomlinson et al. } \\
\text { (2016) } \\
\text { Chow (2013); } \\
\text { Broekhuizen et al. (2014); } \\
\text { Sport and } \\
\text { recreational } \\
\text { facilities }\end{array}$ \\
$\begin{array}{l}\text { Silver et al. (2014); } \\
\text { Wecial facilities }\end{array}$ & $\begin{array}{l}\text { Azcarate et al. (2016); } \\
\text { Chen et al. (2016) }\end{array}$ \\
\hline
\end{tabular}

\subsection{Maintenance Interval}

The increasing complexity of building and systems has led to the higher maintenance need. Moreover, the maintenance works are different from the construction works in nature and thus, implemented in combination of in-house and outsourced maintenance (Blessing et al., 2015; Hassanain et al., 2015b). Yiu et al. (2002) stated that the maintenance works are usually attended at short notice, and this could lead to problems in resource mobilisation. Meanwhile, the works tend to be in small scale that is difficult to achieve economies of scale, exercise staff, quality control, and utilise resources efficiently. In order to tackle these issues, preventive maintenance should be maximised as it determines the interval or routine of the maintenance works systematically.

Hui (2005) claimed that regular maintenance is compulsory on the building services systems, building components and amenities based on the manufacturer manuals or guidelines, regulations, and industry practices, in order to retain their optimal condition. Hence, the arrangement of maintenance works and resources from the clients, in-house staff and service providers can be well organised and then achieve mutual benefits. However, the maintenance outcome might not be ideal if the interval of maintenance is inaccurate or inappropriate (Edward et al., 1998; Eti et al., 2006; Irigaray \& Gilabert, 2009; Wu et al., 2006). For example, long maintenance interval induces the risk of dilapidation and component failure (Paulo et al., 2014); while short interval incurs more resource allocations.
Therefore, identifying the suitable maintenance interval is needed to achieve positive performance with optimal resources.

\section{RESEARCH METHOD}

The research aimed to investigate the appropriate maintenance interval of different building facilities and services by obtaining opinion of practitioners through questionnaire survey. Whereby, Graziano and Raulin (2010) convinced that questionnaire survey is able to gather respondents' experiences, perceptions, attitudes or practices in their natural environment. Literature review was carried out to identify both essential and value-added building facilities and services as research variables prior to the data collection process. The high-rise residential buildings in Peninsular Malaysia were defined as the research population. According to NAPIC (2016), there were 1902 schemes of high-rise housings in Peninsular Malaysia. Krejcie and Morgan (1970) sample size table indicated that the minimal sample size for research population of 1900 is 320 . Thus, the questionnaire was randomly disseminated to the potential respondents. The respondents were maintenance personnel involved in the high-rise residential buildings, included building manager, building executive or supervisor, building technician, and other building management staff. They were eligible to provide reliable and valid information about the maintenance practice in the residential building they work in. Next, the respondents were acquired to rank the maintenance interval of different building facilities and services based on their experience. The ranking was designed in five-point Likert's scale, namely Least frequent (1), Less frequent (2), Moderate (3), More frequent (4), and Most frequent (5). Eventually, 321 returned questionnaires out of 328 were filtered to be valid for data analysis purpose; whereas the remaining seven were incomplete and thus excluded from analysis process. The analysis method adopted for identifying the rank of maintenance intervals was mean analysis. In order to compare the differences among the maintenance intervals of facilities and services, Friedman test was performed. It is suitable to compare related samples in ordinal scale (Chua, 2009; Coakes \& Ong, 2011). Besides that, reliability analysis was conducted for the research variables to check the consistency of the scale of data and assess the reliability of the data (Leech et al., 2011). The Cronbach's alpha coefficient test indicated that the coefficient for the variables was 0.867 . Whereby, a coefficient of more than 0.70 indicates good reliability. 


\section{FINDINGS AND DISCUSSION}

All the essential and value-added building facilities and services in high-rise residential building were confirmed through literature review as shown in Table 1 and Table 2 . Subsequently, Table 3 ranks the maintenance intervals of the building facilities and services based on their mean scores. Lift system was the most frequent maintained or inspected, comparing with other building facilities and services. Its mean score was 4.19 and placed on top of the rank table. Commonly, the lift maintenance is outsourced to the qualified service provider with appropriate contractual agreement. The maintenance or inspection interval is clearly spelled out in the contract. The frequent and regular maintenance is usually imposed to comply with legislation and maintenance guidelines (Alonso Pérez et al., 2010).

Then, maintenance intervals of power supply and water supply systems were both ranked second with mean score of 4.05 . As the utility supplies are the basic need of the people to perform their daily activities nowadays, the maintenance of the power and water supply systems are emphasised. The utility supply systems are more complex in high-rise housing as they have distribution systems to cater usage of multiple dwelling units. For instance, the power supply system is installed with floor distribution board and water supply system is equipped with water pump in high-rise building. The failure of these components might lead to supply interruption to multiple dwelling units. Therefore, timely maintenance of these systems is essential to prevent outright system failure (Goulden \& Spence, 2015; Hassanain et al., 2015a).

Table 3: Ranking analysis of maintenance interval towards building facilities and services

\begin{tabular}{llrr}
\hline Rank & $\begin{array}{l}\text { Maintenance } \\
\text { Interval }\end{array}$ & $\begin{array}{r}\text { Mean } \\
(\mathrm{N}=321)\end{array}$ & $\begin{array}{r}\text { Standard } \\
\text { Deviation }\end{array}$ \\
\hline 1 & Lift system & 4.19 & .777 \\
2 & Power supply & 4.05 & .738 \\
2 & Water supply & 4.05 & .767 \\
4 & Cleaning & 4.04 & .761 \\
& services & & \\
5 & Fire & 4.01 & .783 \\
& protection & & \\
& system & & .810 \\
6 & Security & 3.93 & \\
& system & & .728 \\
7 & Landscaping & 3.82 & \\
& and & & .867 \\
\hline \multirow{2}{*}{8} & gardening & & \\
\hline
\end{tabular}

\begin{tabular}{llll}
\hline & pool & & \\
9 & Sport and & 3.52 & .895 \\
& $\begin{array}{l}\text { recreational } \\
\text { facilities }\end{array}$ & & \\
10 & Painting & 3.46 & .890 \\
11 & Social & 3.45 & .948 \\
& facilities & & \\
\hline
\end{tabular}

Furthermore, the routine of cleaning service was ranked fourth, with mean score of 4.04. Cleaning of common area in high-rise housings is usually done by the cleaners, either in-house or outsource. The regular cleaning maintenance ensures the hygienic living environment as demanded by the residents. Meanwhile, it deals with safety and health concerns as mentioned by Choi et al. (2015) and Leone et al. (2015). For example, greasy floor surface is prone to the risk of slipping or falling that causes injury. Additionally, untimely disposal of garbage bins leads to the growth of viruses and bacteria that might be harmful to the human health.

Next, the maintenance interval of fire protection system was ranked fifth, with mean score of 4.01. In Malaysia, regular inspection of fire protection system in the buildings is mandatory as stipulated by the Fire and Rescue Department Malaysia (FRDM) (Azmi et al., 2009). Meanwhile, the renewal of fire insurance is subjected to the installation and functionality of fire protection system. Thus, the upkeep of fire protection system ensures the protection of building assets in case of fire event (Xin \& Huang, 2013), as well as insurance coverage under the fire insurance policy.

The remaining six facilities and services were ranked at the bottom of the table, with mean scores of less than 4.00. Five out of the six facilities and services were actually value-added facilities and services, namely landscaping and gardening, swimming pool, sport and recreational facilities, painting, and social facilities. They neither possess safety and health concerns nor necessary for the daily activities of the residents. Thus, the maintenance intervals of these facilities and services were deemed not critical as of the essential facilities and services.

In order to investigate whether there was any significant difference among the maintenance intervals of respective building facilities and services, Friedman test was run using SPSS. The results of Friedman test as tabulated in Table 4 indicates that significant differences did exist in the maintenance intervals across the building facilities and services, $\chi^{2}(10, \mathrm{~N}=321)=$ 473.977, $\mathrm{p}<0.05$. The maintenance intervals of added-value facilities and services were 
considerably less frequent compared to the essential facilities and services, as demonstrated by the mean scores in Table 3 .

Table 4: Friedman test statistics

\begin{tabular}{lr}
\hline N & 321 \\
Chi-Square & 473.977 \\
df & 10 \\
Asymp. Sig. & .000 \\
\hline
\end{tabular}

In summary, the results confirmed that each of the facilities and services has its own suitable maintenance interval rather than all having the same interval. Hence, there is a need to investigate the maintenance need of the facilities and services based on the aspects of safety and health, risk, life cycle, etc. Since the building managers have to manage the maintenance of facilities and services within a limited budget without jeopardising the functionality (Au-Yong et al., 2017; Blessing et al., 2015), the result of this paper can be used as a reference for them to plan and prioritise the maintenance interval of different facilities and service.

\section{CONCLUSION}

Generally, the result revealed that it is essential for the building personnel to determine the appropriate maintenance interval for each type of facilities and services before planning the maintenance work as whole. The findings revealed that essential building facilities and services should be prioritised compared to valueadded facilities as the essential elements cold affect the safety and well-being of the building occupants. However, due to the demand of user for more facilities to have better quality of life and to achieve work life balance, various facilities and services have been provided. Nonetheless, the maintenance list become longer and the maintenance task becoming more challenging. Thus, it is more crucial for the building manager to set appropriate maintenance interval for each facilities and services so that the building can operate optimum even with limited resources. The result of this research indicates the common practice of maintenance intervals in the industry. It is helpful for the practitioners to plan the maintenance interval of each facilities and services. Anyway, future research is recommended to investigate the relationship between maintenance intervals and building performance. It is aimed to utilise the maintenance resources through maintenance prioritisation without jeopardising the performance.

\section{ACKNOWLEDGEMENT}

The authors gratefully acknowledge the financial support of the University of Malaya Research Fund Assistance (BKP), grant no. BK021-2015 established at the Institute of Research Management \& Monitoring (IPPP), University of Malaya.

\section{REFERENCES}

Abd Wahab, S. R. H., Che Ani, A. I., Sairi, A., Mohd Tawil, N., \& Abd Razak, M. Z. (2016). Classification of High-Rise Residential Building Facilities: A Descriptive Survey on 170 Housing Scheme in Klang Valley. MATEC Web Conf., 66, 00103.

Abdul Karim, H. (2012). Low Cost Housing Environment: Compromising Quality of Life? Procedia - Social and Behavioral Sciences, 35, 44-53.

Abdullah Sani, S. I., Mohammed, A. H., Misnan, M. S., \& Awang, M. (2012). Determinant factors in development of maintenance culture in managing public asset and facilities. Procedia - Social and Behavioral Sciences, 65, 827-832.

Ait Bamai, Y., Araki, A., Kawai, T., Tsuboi, T., Saito, I., Yoshioka, E., Cong, S., \& Kishi, R. (2016). Exposure to phthalates in house dust and associated allergies in children aged 612 years. Environment International, 96, 1623.

Alonso Pérez, A., Vieira, A. C. V., \& Marques Cardoso, A. J. (2010). School Buildings Assets - Maintenance Management and Organization for Vertical Transportation Equipment. In D. Kiritsis, C. Emmanouilidis, A. Koronios \& J. Mathew (Eds.), Engineering Asset Lifecycle Management: 4th World Congress on Engineering Asset Management (WCEAM 2009) (pp. 59-67).

Arkanova, I. A., \& Kuznetsova, K. A. (2016). Characteristic Features of the WaterTreatment System Design for Outdoor Pools in the Urals. Procedia Engineering, 150, 2352-2357.

Au-Yong, C. P., Ali, A. S., \& Ahmad, F. (2016). Enhancing Building Maintenance Cost Performance with Proper Management of Spare Parts. Journal of Quality in Maintenance Engineering, 22(1), 51-61.

Au-Yong, C. P., Ali, A. S., Ahmad, F., \& Chua, S. J. L. (2017). Influences of key stakeholders' involvement in maintenance management. Property Management, 35(2), 217-231.

Azcarate, I., Gutierrez, J. J., Lazkano, A., Saiz, P., Redondo, K., \& Leturiondo, L. A. (2016). Towards limiting the sensitivity of energy- 
efficient lighting to voltage fluctuations. Renewable and Sustainable Energy Reviews, 59, 1384-1395.

Azmi, H., Shuaib, N. A., Ghazali, M. F., \& Zain', M. Z. M. (2009, 1-2 December 2009). Fire Alarm System, Portable Fire Extinguisher and Hose Reel System Maintenance for Safety Purpose and Requirements. Paper presented at the National Symposium on Advancements in Ergonomics and Safety (ERGOSYM2009), Perlis.

Blessing, O., Richard, J., \& Emmanuel, A. (2015). Assessment of building maintenance management practices of higher education institutions in Niger State - Nigeria. Journal of Design and Built Environment, 15(2), 114.

Broekhuizen, K., Scholten, A.-M., \& de Vries, S. I. (2014). The value of (pre)school playgrounds for children's physical activity level: a systematic review. The International Journal of Behavioral Nutrition and Physical Activity, 11, 59.

Caballé, N. C., Castro, I. T., Pérez, C. J., \& Lanza-Gutiérrez, J. M. (2015). A conditionbased maintenance of a dependent degradation-threshold-shock model in a system with multiple degradation processes. Reliability Engineering and System Safety, 134, 98-109.

Chen, T., Hui, E. C.-M., Lang, W., \& Tao, L. (2016). People, recreational facility and physical activity: New-type urbanization planning for the healthy communities in China. Habitat International, 58, 12-22.

Chiang, Y. H., Li, J., Zhou, L., Wong, F. K. W., \& Lam, P. T. I. (2015). The nexus among employment opportunities, life-cycle costs, and carbon emissions: a case study of sustainable building maintenance in Hong Kong. Journal of Cleaner Production, 109, 326-335.

Choi, S.-k., Kudoh, R., Koga, J., Mikami, T., Yokoyama, Y., Takahashi, H., \& Ono, H. (2015). A comparative evaluation of floor slip resistance test methods. Construction and Building Materials, 94, 737-745.

Chow, H. W. (2013). Outdoor fitness equipment in parks: a qualitative study from older adults' perceptions. BMC public health, 13, 1216.

Chua, Y. P. (2009). Asas Statistik Penyelidikan: Analisis Data Skala Ordinal Dan Skala Nominal Buku 3. Kuala Lumpur: McGrawHill (Malaysia) Sdn. Bhd.

Coakes, S. J., \& Ong, C. (2011). SPSS: Analysis without Anguish: Version 18.0 for Windows. Milton: John Wiley \& Sons Australia, Ltd.
Edward, D. J., Holt, G. D., \& Harris, F. C. (1998). Predictive Maintenance Techniques and Their Relevance to Construction Plant. Journal of Quality in Maintenance Engineering 4(1), 25-37.

Eti, M. C., Ogaji, S. O. T., \& Probert, S. D. (2006). Development and implementation of preventive-maintenance practices in Nigerian industries. Applied Energy, 83(10), 11631179.

Fattorini, M., Ceriale, E., Nante, N., Lenzi, D., Manzi, P., Basagni, C., \& Messina, G. (2016). Use of a fluorescent marker for assessing hospital bathroom cleanliness. American Journal of Infection Control, 44(9), 1066-1068.

Festag, S. (2016). False alarm ratio of fire detection and fire alarm systems in Germany - A meta analysis. Fire Safety Journal, 79, 119-126.

Fleming, R. P. (2016). Automatic Sprinkler System Calculations. In J. M. Hurley, T. D. Gottuk, R. J. Hall Jr., K. Harada, D. E. Kuligowski, M. Puchovsky, L. J. Torero, M. J. Watts Jr. \& J. C. Wieczorek (Eds.), SFPE Handbook of Fire Protection Engineering (pp. 1423-1449). New York, NY: Springer New York.

Flores-Colen, I., \& De Brito, J. (2010). A Systematic Approach for Maintenance Budgeting of Buildings Facades Based on Predictive and Preventive Strategies. Construction and Building Materials, 24(9), 1718-1729.

Forster, A. M., \& Kayan, B. (2009). Maintenance for Historic Buildings: A Current Perspective. Structural Survey, 27(3), 210-229.

Goulden, M., \& Spence, A. (2015). Caught in the middle: The role of the Facilities Manager in organisational energy use. Energy Policy, 85, 280-287.

Graziano, A. M., \& Raulin, M. L. (2010). Research Methods: A Process of Inquiry (7th ed.). Boston: Pearson Education Inc.

Hameed, A., Khan, F., \& Ahmed, S. (2016). A risk-based shutdown inspection and maintenance interval estimation considering human error. Process Safety and Environmental Protection, 100, 9-21.

Harris, B. P. (2011). Lifts for Firefighters. Meeting The Requirement of Chapter 56 Safety Services of BS7671:2008, 12-18.

Hassanain, M., Fatayer, F., \& Al-Hammad, A. (2015a). Design-Phase Maintenance Checklist for Electrical Systems. Journal of Performance of Constructed Facilities, 30(2), 6015003.

Hassanain, M. A., Assaf, S., Al-Hammad, A.-M., \& Al-Nehmi, A. (2015b). A multi-criteria 
decision making model for outsourcing maintenance services. Facilities, 33(3/4), 229-244.

Hui, E. Y. Y. (2005). Key success factors of building management in large and dense residential estates. Facilities, 23(1/2), 47-62.

IFMA. (2015). Essentials of Facility Management Retrieved 27 November, 2015 , from http://www.ifma.org/professionaldevelopment/new-to-facility-managementessentials-of-facility-management

Irigaray, A. A., \& Gilabert, E. (2009). Ubiquitous Computing for Dynamic Condition-Based Maintenance. Journal of Quality in Maintenance Engineering, 15(2), 151-166.

Kamarazaly, M. A., Mbachu, J., \& Phipps, R. (2013). Challenges faced by facilities managers in the Australasian universities. Journal of Facilities Management, 11(2), 136-151.

Korpela, J., Miettinen, R., Salmikivi, T., \& Ihalainen, J. (2015). The challenges and potentials of utilizing building information modelling in facility management: the case of the Center for Properties and Facilities of the University of Helsinki. Construction Management and Economics, 33(1), 3-17.

Krejcie, R. V., \& Morgan, D. W. (1970). Determining Sample Size for Research Activities. Educational and Psychological Measurement, 30, 607-610.

Leech, N. L., Barrett, K. C., \& Morgan, G. A. (2011). IBM SPSS for Intermediate Statistics: Use and Interpretation (4th ed.). New York: Taylor and Francis Group, LLC.

Leone, C. M., Jayasekara, L., Sharp, J., \& Fraser, A. (2015). Prevention and control practices for human noroviruses in long-term care facilities in South Carolina. American Journal of Infection Control, 43(12), 12761280.

Lo, T. Y., Liao, W., K. Wong, C., \& Tang, W. (2016). Evaluation of carbonation resistance of paint coated concrete for buildings. Construction and Building Materials, 107, 299-306.

Meng, X. (2013). Involvement of Facilities Management Specialists in Building Design: United Kingdom Experience. Journal of Performance of Constructed Facilities, 27(5), 500-507.

Mohit, M. A., Ibrahim, M., \& Rashid, Y. R. (2010). Assessment of residential satisfaction in newly designed public low-cost housing in Kuala Lumpur, Malaysia. Habitat International, 34(1), 18-27.

Moreno-Muñoz, A., Dolores Redel, M., Oterino, D., \& De la Rosa, J. J. G. (2007). Quality standards for "clean" electrical supplies. Facilities, 25, 61-77.

NAPIC. (2016). Property Stock Report H1 2016. Putrajaya: Valuation and Property Services Department Malaysia.

Olesen, T., Menzel, C. M., Mcconchie, C. A., \& Wiltshire, N. (2013). Pruning to control tree size, flowering and production of litchi. Scientia Horticulturae, 156, 93-98.

Othman, N., Mohamed, N., \& Hisham, M. (2015). Landscape Aesthetic Values and Visiting Performance in Natural Outdoor Environment. Procedia - Social and Behavioral Sciences, 202, 330-339.

Pan, H., Yang, Z., \& Xu, F. (2016). Study on concrete structure's durability considering the interaction of multi-factors. Construction and Building Materials, 118, 256-261.

Park, S., Sahleh, V., \& Jung, S.-Y. (2015). A system dynamics computer model to assess the effects of developing an alternate water source on the water supply systems management. Procedia Engineering, 119, 753-760.

Paulo, P. V., Branco, F., \& de Brito, J. (2014). BuildingsLife: a building management system. Structure and Infrastructure Engineering, 10(3), 388-397.

Righi, E., Fantuzzi, G., Predieri, G., \& Aggazzotti, G. (2014). Bromate, chlorite, chlorate, haloacetic acids, and trihalomethanes occurrence in indoor swimming pool waters in Italy. Microchemical Journal, 113, 23-29.

Said, A. M., Quiroz, O. I., Hatchett, D. W., \& Elgawady, M. (2016). Latex-modified concrete overlays using waste paint. Construction and Building Materials, 123, 191-197.

Silver, D., Giorgio, M., \& Mijanovich, T. (2014). Utilization patterns and perceptions of playground users in New York City. Journal of Community Health, 39(2), 363371.

Suárez-Warden, F., \& Mendívil, E. G. (2015). Test of Voltage for Electrical Diagnosis Aided by AR in Equipment Adaptation or Predictive Maintenance. Procedia Computer Science, 75, 237-244.

Suruhanjaya Tenaga. (1994). Electricity Regulations 1994 P.U. (A) 38/94: Suruhanjaya Tenaga.

Tardif, R., Catto, C., Haddad, S., Simard, S., \& Rodriguez, M. (2016). Assessment of air and water contamination by disinfection byproducts at 41 indoor swimming pools. Environmental Research, 148, 411-420.

Tiun, L. T. (2009). Managing High-Rise Residential Building in Malaysia: Where are 
We? Paper presented at the 2nd NAPREC Conference, Bangi, Selangor.

Tomlinson, A., Drikas, M., \& Brookes, J. D. (2016). The role of phytoplankton as precursors for disinfection by-product formation upon chlorination. Water Research, 102, 229240.

Walker, H., \& Tough, A. (2015). Facial Comparison from CCTV footage: The competence and confidence of the jury. Science and Justice, 55(6), 487-498.

Weissfeld, A. S. (2015). Infections at the Gym. Clinical Microbiology Newsletter, 37(11), 87-90.

Williamson, A., Tsay, L. S., Kateeb, I. A., \& Burton, L. (2013). Solutions for RFID Smart Tagged Card Security Vulnerabilities. AASRI Procedia, 4, 282-287.

$\mathrm{Wu}$, S., Clements-Croome, D., Fairey, V., Albany, B., Sidhu, J., Desmond, D., \& Neale, K. (2006). Reliability in the Whole Life Cycle of Building Systems. Engineering, Construction and Architectural Management, 13(2), 136-153.

Wu, X., Yuan, J., Luo, A., Chen, Y., \& Fan, Y. (2016). Drought stress and re-watering increase secondary metabolites and enzyme activity in dendrobium moniliforme. Industrial Crops and Products, 94, 385-393.

Xin, J., \& Huang, C. (2013). Fire risk analysis of residential buildings based on scenario clusters and its application in fire risk management. Fire Safety Journal, 62, 72-78.

Yang, L., Ma, X., Zhai, Q., \& Zhao, Y. (2016). A delay time model for a mission-based system subject to periodic and random inspection and postponed replacement. Reliability Engineering \& System Safety, 150, 96-104.

Yao, H. W., Zhang, P., Zheng, Y. P., \& Liang, D. (2016). Introduction for Code for Design of Automatic Fire Alarm System. Procedia Engineering, 135, 67-71.

Yiu, C. Y., Lo, S. M., Thomas Ng, S., \& Michael $\mathrm{Ng}$, M. F. (2002). Contractor selection for small building works in Hong Kong. Structural Survey, 20(4), 129-135.

Yusof, N. A., Abdullah, S., Zubedy, S., \& Mohd Najib, N. U. (2012). Residents' maintenance priorities preference: the case of public housing in Malaysia. Procedia - Social and Behavioral Sciences, 62, 508-513.

Zairul, N. M., Abdul, G. S., Aini, A. M., Aziz, W., Hanif, N. R., Al-Sadat, Z., \& Tedong, P. A. (2015, 09-12 April). Issues in Managing Vertical Residential Building in Malaysia. Paper presented at the Asia Pacific Network for Housing Research Conference (APNHR), Gwangju, South Korea.
Zawawi, E. M. A., Kamaruzzaman, S. N., Ithnina, Z., \& Zulkarnain, S. H. (2011). A Conceptual Framework for Describing CSF of Building Maintenance Management. Procedia Engineering, 20, 110-117. 